\title{
Cornish Language
}

National Cancer Institute

\section{Source}

National Cancer Institute. Cornish Language. NCI Thesaurus. Code C153887.

A Southwestern Brittonic Celtic language that is native to Cornwall in south-west England. 